\title{
The Mediating Role of Dynamic Capabilities and Business Model Innovation on the Relationship Between Environment Turbulence and Firm Performance
}

\author{
Dudi Hendra Fachrudin* \\ Sekolah Tinggi Manajemen Logistik Indonesia \\ Logistics Management \\ Bandung, Indonesia \\ *dudi_hendra@stimlog.ac.id
}

\author{
Agus Rahayu, Nanang Fattah, Lili Adi Wibowo \\ Universitas Pendidikan Indonesia \\ Bandung, Indonesia \\ agus_rahayu08@upi.edu,nanangfattah@yahoo.com, \\ liliadiwibowo@upi.edu
}

\begin{abstract}
This paper describes the impact of environmental turbulence on the company's business model that has led to a global recession. What is surprising is that the cause of the 2020 recession is Covid-19, which is a health crisis, but has an impact on the world economic crisis. Background Problems: The world economic crisis requires all companies to change their strategies and business models significantly in order to maintain the company's survival. This paper tries to examine how companies survive and try to get out of a crisis with no certainty over. Novelty: Changes in the business model of this crisis era require a strong dynamic capability of the company to be able to modify the existing factors in the business model canvas. Changes include activities in creating new strategies based on Sense, Seize and Transform on dynamic capabilities. Research Methods: This paper is the initial part of the author's dissertation plan that takes the theme of the relationship between environment turbulence, business model innovation, dynamic capabilities and sustainable firm performance. Compiled as a literature review that links the logical relationship between these various factors. Data were taken from various literatures and formulated qualitatively descriptively to determine the phenomena that occurred in companies in the era of the Covid-19 crisis. The industries sampled in this paper are companies in the field of courier and logistics. Finding / Results: This paper presents a research model to examine the importance of companies changing their business model which is based on the company's dynamic capabilities and business model innovation to maintain continuity of company life. Conclusion: This paper has been able to formulate efforts to maintain and adjust the competitiveness of companies in the crisis era, especially the crisis caused by Covid19.
\end{abstract}

Keywords-business model, business model innovation, covid19, dynamic capabilities, firm performance

\section{INTRODUCTION}

The digital economy era and new knowledge have shaped major changes in the business world. Organizations now face stiff competition in a dynamic, uncertain, transformative and complex environment. In order to achieve competitive advantage and even to survive, companies are highly dependent on their ability to adapt and respond to the environment, flexibility and ability to introduce new ideas and products. Changes in the global economy are so fast, sometimes not anticipated by the perpetrators, history has recorded various global economies so that there has been a very wide recession, such as the 1997 Asian debt crisis, the 2008 global financial crisis, the 2010 recession in Greece, the 2016 recession in Nigeria [1-3].

The 2020 global recession is caused by something new in the world, corona virus 2019 (Covid-19). Kate Brown [4] states that the Covid-19 pandemic is not a natural disaster, nor is it an ordinary public health crisis but more of an ecological problem. The coronavirus has hampered economic activity, which has led to the closure of business centers. Covid-19 crisis has now reached a new critical phase and has had a significant impact on the economy. Many companies felt, reacted to, and understood the lessons of this fast-paced event. Covid-19 is not a one-time challenge.

Increasing uncertainty about how bad the situation will lead to economic problems among business actors domestic and international and their trading partners. International Monetary Funds (IMF) stated that the world economy was depressed and it is estimated that it will experience a recession in 2020 in the second and third quarters of 2020, and began to rise again in the fourth quarter as shown in Table 1. below [5]. 
TABLE I. ECONOMIC PRESSURES DUE TO COVID-19 [5]

\begin{tabular}{|l|c|c|c|c|c|c|c|c|}
\hline & 2018 & 2019 & \multicolumn{3}{|c|}{$\mathbf{2 0 2 0} *$} & \multicolumn{3}{|c|}{$\mathbf{2 0 2 1}^{*}$} \\
\cline { 4 - 9 } & & & $\boldsymbol{F E B}$ & $\boldsymbol{A P R}$ & $\boldsymbol{M E I}$ & $\boldsymbol{F E B}$ & $\boldsymbol{A P R}$ & $\boldsymbol{M E I}$ \\
\hline PDB & \multirow{2}{*}{3.6} & 2.9 & 3.0 & -2.0 & -2.2 & 3.4 & 5.1 & 5.2 \\
\hline AS & 2.9 & 2.3 & 2.1 & -3.7 & -3.7 & 2.0 & 4.3 & 4.3 \\
\hline EURO & 1.8 & 1.2 & 1.1 & -6.1 & -6.1 & 1.3 & 3.2 & 3.2 \\
\hline JEPANG & 0.8 & 0.8 & 0.4 & -4.9 & -5.1 & 0.7 & 2.6 & 2.7 \\
\hline TIONGKOK & 6.6 & 6.1 & 5.6 & 2.1 & 1.8 & 6.2 & 7.9 & 8.0 \\
\hline INDIA & 7.4 & 5.1 & 5.5 & 2.0 & 1.5 & 6.2 & 6.8 & 6.8 \\
\hline LATAM & 1.0 & 0.1 & 1.8 & -5.0 & -5.0 & 2.0 & 3.2 & 3.2 \\
\hline
\end{tabular}

The Governor of Bank Indonesia stated that Covid-19 was a global humanitarian crisis that had never existed before and caused a crisis with a high level of uncertainty as shown in Figure 1.

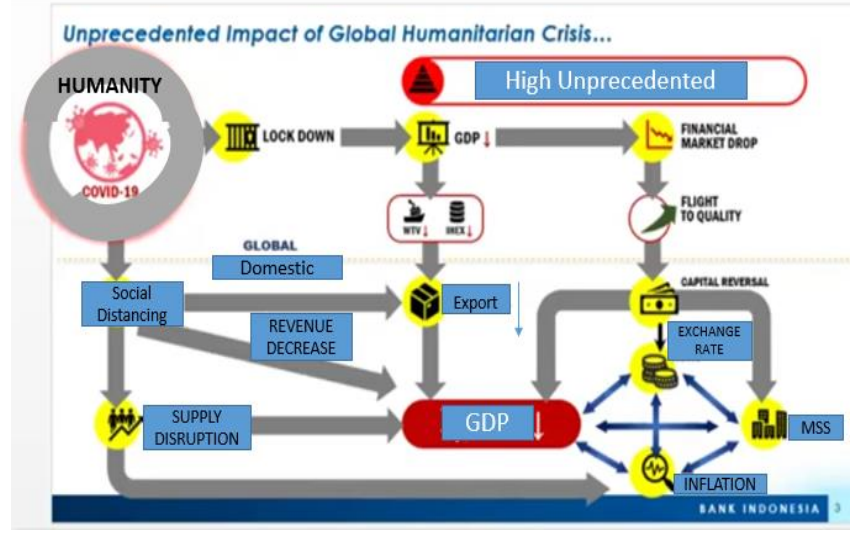

Fig. 1. Unprecedented impact of global humanitarian crisis [5].

In Indonesia itself, the COVID-19 outbreak has greatly affected the supply chain nets carried out by logistics businesses, they must immediately adjust business models and prepare new strategies to be able to survive, as well as be ready to face business changes after the global pandemic has passed, said Mark Plus CEO, Hermawan Kartajaya. He further explained that currently is a crucial period for logistics business actors to survive (surviving) or servicing, as well as preparing [6]. Chairman of the Regional Management Board (DPW) of the Association of Indonesian Express, Postal and Logistics Service Companies (Asperindo) West Java (Jabar), Wayan Wardhana, stated that express, postal and logistics service companies must accelerate the adoption of digital technology and the need for collaboration between Asperindo members in facing the acceleration of digital adoption [7]. In line with Wayan, Ignasius Jonan, former President Director of PT Kereta Api Indonesia, stated that everyone will adjust to social distancing or physical distancing, including doing business so that business actors need to restructure their business with customers to become consultants for customers. The Indonesian logistics industry is still weak in the use of information technology (IT) [6]. Chairman of the Asperindo Association, Mohamad Feriadi, said that the future will come sooner, those who can survive are those with extensive physical networks, good technology, and the right business model. The business segment in freight forwarding is under pressure, especially for the Business to Business (B2B) and Government to Government (G2G) businesses. Several logistics companies are changing their business models to much-needed shipping businesses such as C2C and B2C and increasing technology improvements to sustain the business [8]

Meanwhile, President Director of PT Lookman Djaja, Kyatmaja Lookman revealed, the Covid-19 outbreak had a major impact on the freight or trucking business, especially having to adjust operations and costs to increase driver safety and increase costs to prevent the spread of the virus amid social restriction policies in various area. Changes in logistics business behavior since the Covid-19 outbreak have begun to change, this was conveyed by the General Chair of the Indonesian Logistics Association (ALI), Zaldy Masita, the growth of the logistics business has experienced a sharp contraction, especially business to business (B2B) logistics transporting manufactured products. Meanwhile, business to consumer (B2C) and consumer to consumer (C2C) services are relatively able to survive [6].

Trisnawan Sanjaya, Deputy Head of the Indonesian Logistics and Forwarders Association (ALFI) DPP, also acknowledged the decline in the logistics business in the field of Supply Chain \& E-Commerce. According to him, retail and courier will grow, but bulky or containers will definitely fall. As an illustration, ship calls (in Tanjung Priok) fell from 150 ships to 50 ships. Likewise, cargo at the airport (SoekarnoHatta) from 50 aircraft dropped to 35 aircraft. Trisnawan said that the current developments in the logistics business require a supply chain redesign in anticipation of post-Covid-19 business changes. With the enforcement of Minister of Transportation Regulation No. 25 / 2020 concerning restrictions on transportation, there must be a rearrangement of the pattern and schedule of sending goods by air, besides that there is a change in costs to become more expensive. Even though the problem of increasing Air Cargo by airlines has occurred since the beginning of 2019 [9].

Rakhmatika Ardianto, Chairman of the DPP Tariff Division for the National Association of River, Lake and Ferry Transportation Entrepreneurs. Rakhmatika emphasized that the cost of spare parts and ship maintenance, which are mostly imported, has surged due to the weakening rupiah exchange rate against the US dollar and other foreign currencies. Currently, ferry transportation rates in Indonesia are lagging between $30 \%$ and $50 \%$ of operational costs. This obstacle is experienced by many logistics players who carry out B-to-B activities. The increase in business in retail and courier services was acknowledged by Chief Marketing Officer of PT SiCepat Ekspres Indonesia Wiwin Dewi Herawati. He revealed, changes in consumer behavior who are carrying out social distancing have made the demand for courier and expedition services increase. The balance factor of the supply chain ecosystem must be maintained because courier and logistics services will not work if their feeder partners, namely small and medium industries, are exposed to the virus $[6,10]$. 
The company's business model is related to the business innovaton ecosystem. Business models also reflect contextual and conceptual frameworks that are seen as important as practices to fulfill customer needs [11]. With their dynamic capabilities, company's business model should be adapted and redesigned before competitors do. And it is the focus of top management's task to feel, seize, and transform, because they are considered critical to innovating the right business model [12]. The company's performance from the results of previous research is positively influenced by business model innovation $[13,14]$. To explore the relationship between business model innovation and firm performance, argue that the combination of internal and external knowledge by means of creating and capturing value is a key feature of business model innovation. They tested the effect of these combinations and interactions on sales growth by collecting data from companies in the UK, Germany, France and Italy. The results showed that companies with a low level of internal knowledge had very little effect on sales growth absorbing external information. In contrast, knowledge-intensive firms are relatively freer in defining their knowledge source strategies. The opportunity to gain competitive advantage, according to their research, is mediated by business model innovation in an effort to influence company performance. Therefore, to obtain higher performing opportunities, companies must innovate in their business models to exploit the opportunities.
Several previous studies have partially discussed some of the variables in this study and their respective relationships, including the environment [15], business model innovation, dynamic capabilities [16], and firm performance. The author feels that this research is important to do as a step of improvement and learning from various crises, and as stated by Hermawan Kertajaya [6], after we are surviving, we must serve again (servicing), and at the same time prepare to be better prepared to face a crisis with better risk management. Because it is indicated that companies still ignore risk management factors in their business models or strategic planning [17].

\section{LITERATURE REVIEW}

\section{A. Strategic Management}

According to Wheelen and Hunger [18], in the long-term, company need a set of managerial decisions and actions to have a sustainable performance. This includes external environmental analysis and internal environmental analysis, strategy formulation or formulation related to company planning or long-term corporate strategy, shown in Figure 2.

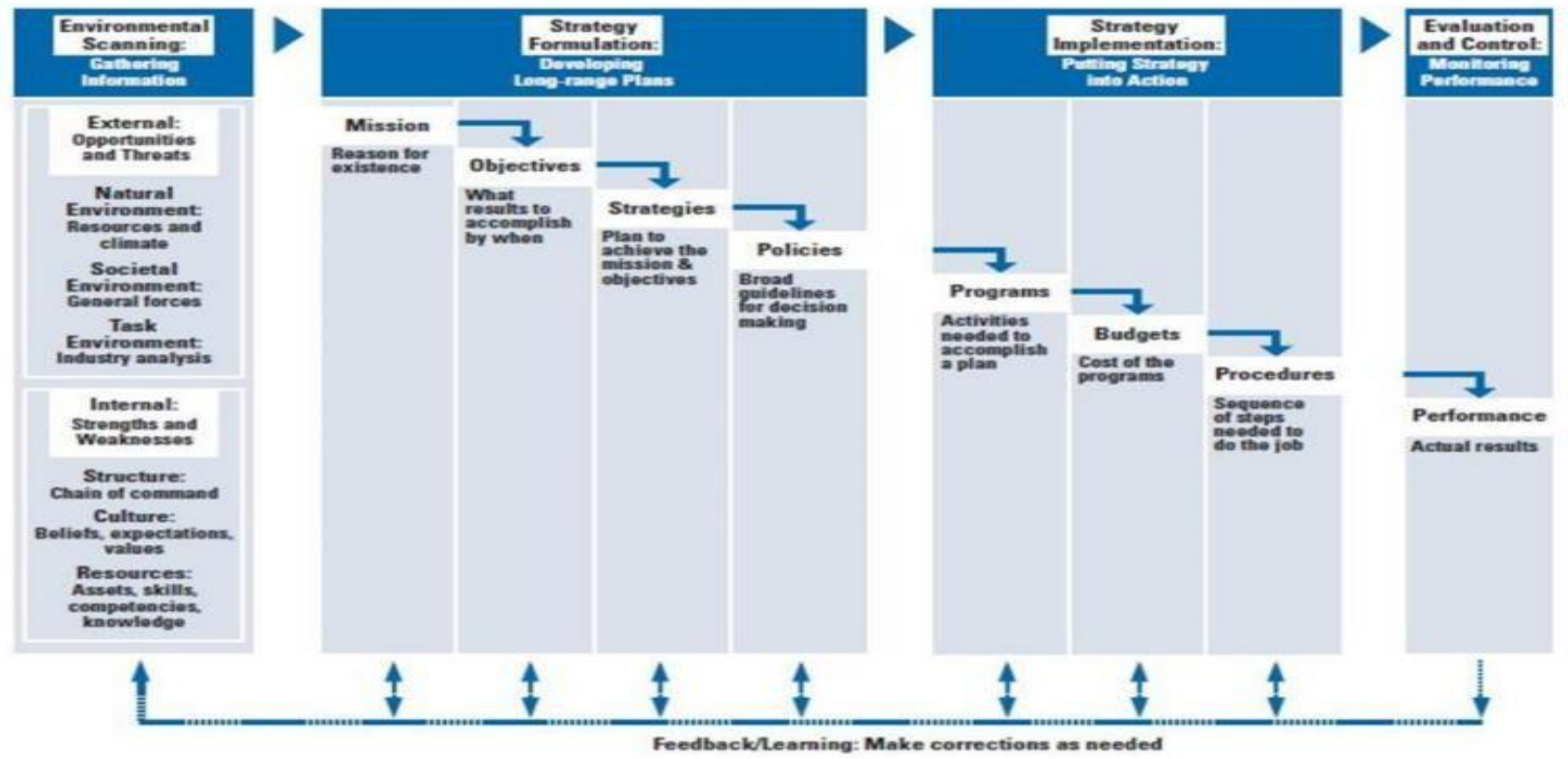

Fig. 2. Strategic management model [18]

\section{B. Firm Performance}

Business success is measured by financial performance, operations, revenue and the level of service to its customers. The company's performance shows whether an organization is effective or not in running its business [19] furthermore companies need to better understand the growth of company performance through new business opportunities in order to find out market expectations [20]. Kaplan and Norton created a Balanced Scorecard to develop an assessment of company resources that will increase the company's total assets [21]. Ogunsiji and Ladanu [2] confirm that this measurement is to translate intangible assets into financial results [2]. As stated by Pauwels et al. [22], Sorescu and Spanjol [23], and Srinivasan et al. [24] performance can be in the form of position on market, 
finance and corporate value. Market position is based on the company's revenue results such as sales, market share and sales growth. The financial position is the result of calculating the cost components of the company's activities such as the ability to earn profits, the ability to return assets, the ability to return on investment, and the return on equity. Meanwhile, firm value is the company's performance on the stock market, market capitalization, and the ratio of the market to book prices.

\section{Dynamic Capabilities}

Dynamic capabilities means an organizational effort and strategic activities to achieve new resource arrangements, which are the core competencies of an organization in maintaining its competitive advantage. In e-commerce, this dynamic capabilities are competencies to keep the company competitive. Dynamic capabilities are also defined as the combination of resources and competencies in managing knowledge resources and creating new things from that knowledge to become a competitive advantage. Resources here are tangible and intangible resources. Competence development is very necessary for e-commerce, considering that e-commerce is very sensitive to environmental changes, so it must always be creative and innovative in order to be able to adapt to new environments. Sensing opportunities and threats (sensing), finding new activities to fill opportunities (seizing) and forming new systems (forming) are the domains of dynamic capabilities. Sensing, seizing and transform abilities are dimensions of dynamic capabilities to withstand environmental turbulence through their competitive advantage $[12,25]$ can be seen in Figure 3.

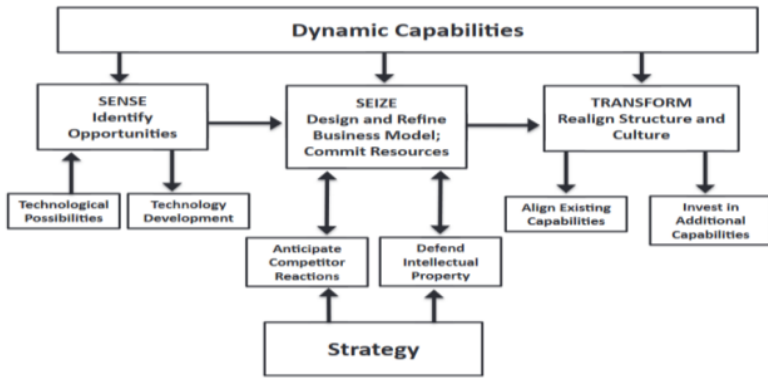

Fig. 3. Dynamic capabilities, busines model and strategy [12]

\section{Business Model and Business Model Innovation}

There are various definitions of a business model [16] which describe value creation, value capture, and value delivery by companies. George and Bock [1] stated that a business model is the design of an organizational structure to impose commercial opportunities; another suggests that, Teece [26] states that a business model will be created along with the formation of a business company, either explicitly or implicitly to implement a value creation, delivery and capture mechanism for services from the company. Meanwhile, Mitchel and Coles [27] argue that the business model is all about preparing products and services for customers, in essence it is the answer to the question of what, who, why, when, how and how much.
Everything is done to achieve the expected performance, of course, superior performance. Performance excellence must be maintained and developed through technological, organizational and marketing innovation. Internally, innovation can be in the form of new ways of managing routine work within the organization, or externally managing relationships with partners, suppliers and customers [28].

\section{E. Environment Turbulence}

Mintzberg [29] defines the business organizational environment as an external influence in the form of patterns and conditions on life and business and organizational development. Organizational environment is also defined as something that cannot be predicted because change is very substantial, sustainable but uncertain and unstable [30]. Based on the experimental results, the environment is conceptualized as a tool to survive due to continuous fluctuation and its unpredictable shape. To be able to survive in an unstable and possibly volatile environment, organizations must change their business model to be more flexible and innovate in responding to competition quickly, precisely and adequately. The business environment can provide rapid volatility and change to organizations. The turbulence the organization experiences is perceived as a major change, fast-paced, but unsustainable. Turbulence is more radical, non-linear, and often occurs. There are two turbulence parameters presented by Johnson [31], namely dynamics and complexity. The business environment is a pattern of various conditions from outside the organization that will influence the development of organizational business life. Thus the concept of a volatile environment in this study consists of situations that can change continuously, substantially, uncertainly, and unpredictably.

Given that the courier and logistics business is currently based on e-commerce, the information technology used has the same characteristics as the mobile business. There are several dimensions that can be used as benchmarks for a volatile or turbulence environment, namely, market (turbulence of the market environment), competition (turbulence of the competitive environment), technology (turbulence of the technology environment), discrimination by customers and pressure from government and influence groups (regulatory environment turbulence) $[32,33]$.

\section{METHODS}

This paper is the initial part of dissertation proposal. This study used a qualitative method. Literature and discussion is conveyed by descriptive analysis. The data is obtained from various reading sources, including books, journals, and websites on the internet. Thus providing an up-to-date overview of the problems faced and constituting the state-ofthe-art of the body of knowledge in the strategic management field. 


\section{RESULTS}

Relationship between environmental turbulence, dynamic capabilities, business model innovation and firm performance.

In an environment of turbulence full of uncertainty, change is fast, and there is no pattern. Organizations will anticipate by looking at two dynamic conditions in the company, namely: first, evolutionary change, slowly and through stages according to organizational capabilities, and accompanied by continuous improvement. Second, revolutionary change, carried out quickly, radically, and focused on purpose. Thus, it can be seen that dynamic capabilities will respond to environmental changes by engineering according to organizational choices. In other words, there is an effect of dynamic capability with environmental turbulence. Various concepts are put forward to convince that companies must innovate their business models to find new ways of doing business in this complex and dynamic environment. However, some doubt that business model innovation can affect company performance. Referring to this, research model, hypotheses and variables operational are :

\section{A. Research Model}

The research model that describes the frame of mind of this study can be seen in Figure 4 below:

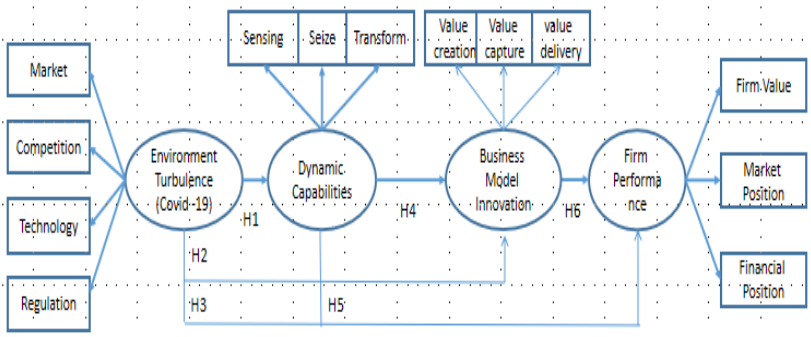

Fig. 4. Research model.

\section{B. Hypotheses}

H1: Environmental turbulencel has a positive effect on the dynamic capabilities of a company.

H2 : Environmental turbulence has a positive effect on the business model innovation

H3 : Environmental turbulence ha a positive effect on firm performance

H4 : Dynamic capabilities has a positive effect on business model innovation

H5 : Dynamic capabilities has a positive effect on firm performance

H6 ::Business model innovation has a positive effect on firm performance

\section{Operational Variables}

This research model consists of 1independent variables, 2 mediating variable, and 1 dependent variable. The operational definitions of each variable are listed in Table 2.

TABLE II. OPERATIONAL DEFINITION OF VARIABLES

\begin{tabular}{|c|l|l|l|}
\hline No & Theory/Concept & \multicolumn{1}{|c|}{ Variables } & \multicolumn{1}{|c|}{ Indicator } \\
\hline 1 & $\begin{array}{l}\text { Environment } \\
\text { Turbulence [33] }\end{array}$ & $\begin{array}{l}\text { Level of support the } \\
\text { environment } \\
\text { turbulence }\end{array}$ & $\begin{array}{l}\text { Market, Competition, } \\
\text { Technology and } \\
\text { Regulation [33] }\end{array}$ \\
\hline 2 & $\begin{array}{l}\text { Dynamic Capabilities } \\
{[12,25]}\end{array}$ & $\begin{array}{l}\text { Level of succees the } \\
\text { dynamic capabilities }\end{array}$ & $\begin{array}{l}\text { Sensing } \\
\text { Seizing } \\
\text { Transform [12,25] }\end{array}$ \\
\hline 3 & $\begin{array}{l}\text { Business Model } \\
\text { Innovation [16,23] }\end{array}$ & $\begin{array}{l}\text { Level of succeses the } \\
\text { business model } \\
\text { innovation }\end{array}$ & $\begin{array}{l}\text { Value creation } \\
\text { Value capture } \\
\text { Value Delivery } \\
{[16,23]}\end{array}$ \\
\hline 4 & Firm performance & $\begin{array}{l}\text { Level of success the } \\
\text { firm performance. }\end{array}$ & $\begin{array}{l}\text { Firm value } \\
\text { Market } \\
\text { Financial position } \\
{[13]}\end{array}$ \\
\end{tabular}

\section{DISCUSSION}

\section{A. Theoretical Contributions}

This study hopes to provide important theoretical contributions in the status of dynamic capabilities and business models of innovation. First, to see the extent of the mediating effect of dynamic capabilities and business model innovation on firm performance. In several studies it has been proven that there is a positive relationship between integrative capabilities and company performance $[34,35]$ but the effect has not been revealed with certainty [36]. Second, to see the extent of the mediating effect of dynamic capability and the innovation business model in relation to environmental turbulence and company performance.

\section{B. Managerial Contributions}

It is hoped that our findings will have several important managerial implications. To improve company performance, company managers should pay more attention to their dynamic capabilities. However, superior performance does not come just like that but through change activities in business model innovation. Business model innovation can recognize opportunities, suitable resources and mitigate risks [36].

\section{CONCLUSION}

From this study, it can be concluded that based on the literature and previous research, a new research model can be created to broaden our insight into the role of dynamic capabilities in anticipating environmental shocks, with the help of business model innovation mediation in order to be able to further maintain company performance. However, at a later stage this research will continue to be carried out with quantitative analysis. To enrich it, other variables can be added either obtained from the results of environmental scanning, 
strategy formulation and strategy implementation such as human resources, entrepreneurship, and risk management.

\section{REFERENCES}

[1] S. Bentolila, M. Jansen, and G. Jiménez, "When credit dries up: Job losses in the great recession," J. Eur. Econ. Assoc., vol. 16, no. 3, pp. $650-695,2018$

[2] A.S. Ogunsiji and W.K. Ladanu, "A theoretical study of performance measures in the strategic and corporate entrepreneurship of firms," Int. J. Life Sci., vol. 1, no. 1, pp. 49-57, 2017.

[3] D.A.M. Rady, "Greece debt crisis: Causes, implications and policy options,” Acad. Account. Financ. Stud. J., vol. 16, p. 87, 2012.

[4] K.R. Brown, P. Hodkinson, N. Smith, A. Hawkey, R. Velho, and P. Carvil, "Why Space: The opportunity for Health and Life Science Innovation," 2021

[5] Governor of Bank Indonesia, IMF-WEO, BI Projection, April 2020. 2020 .

[6] L. Translog Today, "Wabah Covid-19 akan Ubah Wajah Bisnis Logistik, Ini Saran Pakar dan Praktisi.” 2020.

[7] “Asperindo Dorong Anggota Percepat Adopsi Digital, Strategi Jasa Kiriman Sangat Dipengaruhi Oleh Teknologi," PIKIRAN RAKYAT, 2020

[8] CNBC Indonesia, "Closing Bell.” 2020.

[9] KOMPAS.com, "Lion Air Group Enggan Komentari Kenaikan Tarif Surat Muatan Udara,” Kompas.com, JAKARTA, 2019.

[10] Tribunnews.com, "Asperindo: Kenaikan Tarif Kargo Udara Tidak Wajar," Tribunnews.com, 2019.

[11] J.E. Souto, "Business model innovation and business concept innovation as the context of incremental innovation and radical innovation," Tour. Manag., vol. 51, pp. 142-155, 2015.

[12] D.J. Teece, "Business models and dynamic capabilities," Long Range Plann., vol. 51, no. 1, pp. 40-49, 2018

[13] N.J. Foss and T. Saebi, "Fifteen years of research on business model innovation: How far have we come, and where should we go?," J Manage., vol. 43, no. 1, pp. 200-227, 2017.

[14] S. Schneider and P. Spieth, "Business model innovation: Towards an integrated future research agenda," Int. J. Innov. Manag., vol. 17, no. 01, p. $1340001,2013$.

[15] A. Pucihar, G. Lenart, M. Marolt, M. K. Borštnar, and D. Maletič, "Role of ICT in Bussiness Model Innovation in SMEs-Case Of Slovenia," Proc. 24th Interdiscip. Inf. Manag. Talks Inf. Technol. Soc. Econ. Strateg. Cross-Influences, pp. 231-241, 2016.

[16] R.C. Beckett and J. Dalrymple, "Business Model Architecture by Design," Technol. Innov. Manag. Rev., vol. 9, no. 7, 2019

[17] J. Schoenfeld, "The invisible risk: Pandemics and the financial markets," Tuck Sch. Bus. Work. Pap., no. 3567249, 2020.
[18] L.W. Thomas and J.D. Hunger, "Strategic management and business policy: toward global sustainability," Columbus, Bost., 2012.

[19] H. Bouwman, S. Nikou, F. J. Molina-Castillo, and M. de Reuver, "The impact of digitalization on business models," Digit. Policy, Regul. Gov. 2018

[20] Y. Eshima and B.S. Anderson, "Firm growth, adaptive capability, and entrepreneurial orientation," Strateg. Manag. J., vol. 38, no. 3, pp. 770779,2017

[21] R. Kaplan and D. Norton, "The balanced scorecard - measures that drive performance. Harvard Business Review, vol. 14, no. 4, pp. 71-90, 1992.

[22] K. Pauwels, J. Silva-Risso, S. Srinivasan, D. M. Hanssens, and G. Anderson, "New Products, Sales Promotions and Firm Value, With Application to the Automobile Industry," J. Mark., pp. 22-38, 2003.

[23] A.B. Sorescu and J. Spanjol, "Innovation's effect on firm value and risk: Insights from consumer packaged goods," J. Mark., vol. 72, no. 2, pp. 114-132, 2008

[24] S. Srinivasan, K. Pauwels, J. Silva-Risso, and D.M. Hanssens, "Product innovations, advertising, and stock returns," J. Mark., vol. 73, no. 1, pp. 24-43, 2009.

[25] M.P.P. Pieroni, T.C. McAloone, and D.C.A. Pigosso, "Business mode innovation for circular economy and sustainability: A review of approaches," J. Clean. Prod., vol. 215, pp. 198-216, 2019.

[26] D. Airey, Logo design love: A guide to creating iconic brand identities. New Riders, 2009

[27] D. Mitchell and C. Coles, "The ultimate competitive advantage of continuing business model innovation,” J. Bus. Strategy, 2003.

[28] E. Oslo Manual, In Guidelines for Collecting and Interpreting Innovation Data. Paris, France: OECD, 2005.

[29] H. Mintzberg, "The nature of managerial work," 1973

[30] J. Eisenhardt, Kathleen M. Martin, A. Department of Management Science and Engineering,. Stanford, California, U.S.A.: Stanford University,

[31] Johnson G, S.K, and S.RM, Exploring Strategy Managemnt. PrencticeHall, Inc. Ontario., 1989.

[32] H.I. Ansoff, "Strategic issue management," Strateg. Manag. J., vol. 1, no. 2, pp. 131-148, 1980.

[33] Nashirudin, "Envinronmental turbulence and dynamic capabilities: effects on business performance unit through business strategy and competitive advantage, Disertation, Diponegoro University, Semarang, Indonesia.," Disertation. Diponegoro University, Semarang, 2014.

[34] C.E. Helfat and M.A. Campo-Rembado, "Integrative capabilities, vertical integration, and innovation over successive technology lifecycles,” Organ. Sci., vol. 27, no. 2, pp. 249-264, 2016.

[35] J. Liao, J. R. Kickul, and H. Ma, "Organizational dynamic capability and innovation: An empirical examination of internet firms," J. small Bus. Manag., vol. 47, no. 3, pp. 263-286, 2009.

[36] C. Pang, Q. Wang, Y. Li, and G. Duan, "Integrative capability, business model innovation and performance: Contingent effect of business strategy,” Eur. J. Innov. Manag., 2019. 